\title{
LXX. On the resistance of solids; with tables of the specific cohesion and the cohesive force of bodies
}

\author{
Mr. Thomas Tredgold
}

To cite this article: Mr. Thomas Tredgold (1817) LXX. On the resistance of solids; with tables of the specific cohesion and the cohesive force of bodies, Philosophical Magazine Series 1, 50:236, 413-428, DOI: $10.1080 / 14786441708637810$

To link to this article: http://dx.doi.org/10.1080/14786441708637810

里 Published online: 27 Jul 2009.

Submit your article to this journal $\lceil\pi$

Џll Article views: 2

Q View related articles ๘ 
2. You may, therely, with sertuinty, get fruit of every good sort, of which you wish to see the preduce, in the next rear.

3. This method may probably serve to increase conicicrably the quantity of fuit in the comity.

The bran hes so opcrate upon are hung full of frotit, while the others that are not riaged, ofte: have nothing, or very little on them. This ffect is arsy to be explained fiom the thory of the motion of the sap. For, when the sap mores showly in a tree, it protices fruis-burls, whith is tirs case in cld trees; when it moves visurouly, the ree forms root, or runs into shoots, as happens with y whing trass.

Though I arrived at this thenvery myself, in eonsequence of

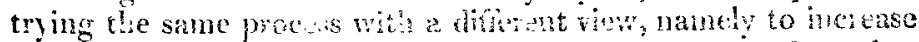

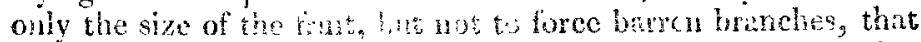

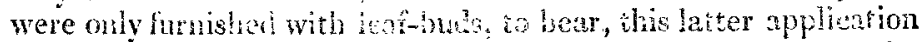
being before quite m?

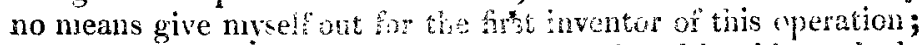
but I was ignorant of the erfocis to be produced by this method, and only discovered then by repeaich wientments of n'y own, which I made for the probotion of ponolow. Frapucit experience of the completest ansess hats coninned the rrath of my observations. Nor do I think that this wisthod is geverally known; at least, to all thws to whom I bhows the experiment,

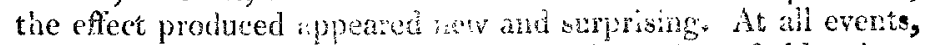
that method, supposing it eves bs be an invention of clder ciate,

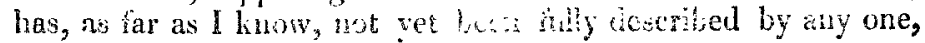
and published in prini.

LXX. On the Resistance of solids; "ith Talles of the specific Cohesion and the cohesice force of Bodie's. By Mr. Trumas TREDGOLD*.

$$
\text { Dofititions, ics. }
$$

1. Conesron, or altraction of entesicnt, is that force by means of which the patides of bories are held together.

When the particles of a body cobere so slighty that they. are easily moved among one another, in every cirection, by a very smail force, the body is called a fuid.

* Communicated by the Author.

4. Of the nature of attracion of cohesion, wuthing in hrown; but the phe. nomena prove the existen': al that pacpery of bodies to which the neme is applice. It is known that the parts of budies do cuhere, and that, wheir ac-

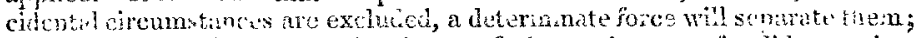
and this force buing giren, the sheory of the resistince of solids consists in nothing mote that applying the priaciples of mechanics to determine the power which will destroy thut cohesiun, when the direction of the power, and the position and ugagnitude of the body, are giren.

When 
When the particles of a body can be moved only in a very small degree, without destroying their cohesion, the body is called a solid.

2. The alsolute cohesion of solids is measured by the force necessary to pull them asunder. Thus, if a rod of iron be suspended in a vertical direction, and weights be attached to its lower extremity till the rod breaks, the whole weight attached to the rod, at the time of fracture, would be the measure of its cohesive force, or absolute coliesion.

3 . The particles of solid bodies, in their natural state, are arranged in such a manner that they are in equilibrio in respect to the forces which operate on them. Therefore, when any new force is applied, it is evident that the equilibrium will be destroyed, and that the particles will move among themselves till it be restored.

When the new force is applied to pull the body asunder, the body becomes longer in the direction of the force; which is called the extension; and its area at right angles to the direction of the force contracts.

When the furce is applied to compress the body, it becomes shorter in the direction of the force, which is called the compression; and the area of its section, at right angles to the force, expands*.

In either case, a part of the heat, or any other fluid, that occupied the pores or interstices of the boly, before the new forcs was made to act upon it, will be expelled $\uparrow$.

4. The depth of a beam, or bar, is the dimension in the direction of the pressure.

\section{Phcenomena.}

5. All bodies, as far as experience reaches, are extended of compressed by an adequate force.

The extensibility of the most brittle bodies may be rendered sensible by forming them into thin plates. Plates of glass bend considerably when they are only supported at the ends; and this bending could not take place unless the body were both conpressible and extensible. Marriotte succeeded in extending some

* The resistance to compression does not arise from any repulsive power in the particles of bodies; indeed, we have not any facts to prove that the particles of any class of bodies actually repel each other; - -is, whenever a body is forced into a less space than it occupies in its natural stute, one of its constituents, at least, is always expelled; and is restored by a species of capillary attraction, as soon as the external force is removed.

+ The disengagement of heat in experiments on the direct cohesion of bodies, appears to have been first noticed by Perronet in his experiments on the strength of iron. Mr. Barlow hus lately observed the saune paienomena in a greater degree, owing to the large size of the bar that was experimented upon-(Ann. of Phil. x.311)-as it is obvions that the guantity of heat disengaged must be proportional to the mignitudc of the body. 
canes of glass, in the direction of their length, which returned to their original length when the weight was removed*.

6. The extension or compression of homogeneous bodies is directly proportional to the force which occasions it; at least in the first degrees of extension or compression.

Thus, if a wire of any metal be extended 1-10th of an inch by a weight of 100 pounds, it would be extended $2-10$ ths by a weight of 200 pounds; $3-10$ ths by 300 pounds, \&c.†; also, if a body be compressed 1-10th of an inch by 100 pounds, it would be compresecd 2-10ths by 200 pounds, \& c.

7. In the first degrees of extension or compression, all homogeneous bodies are extended and compressed in an equal degree by equal forces. That is, if a force of 1000 pounds wouid extend a body 1-10th of its natural length, it would be compressed 1-10th of its natural length by the same force.

It is justly observed by a late writer on this subject, that "so far as this doctrine has been investigated by experiments, its general truth has been amply confirmed; the slight deviations from the exact proportion, which have been discovered in some substances, being far too unimportant to constitute an exception, and merely tending to show that these substances cannot have been perfectly honogeneous, in the sense here attributed to the word +." In making experiments on the extension and compression of bodies, the times of action have not often been attended to with a sufficient degree of accuracy. It is well known that a eertain time must elapse before the weight produces its full effect upon the body, particulurly when the wejght is considerable; and from a few experiments of my own, I am inclined to think, that were the wcight suffered to produce its full effect at each operation, we should find the extension exactly proportional to the force, even to the time of fracture, and it is most probable that the same observation will apply to compression.

8. When a bar or beam is fixed at one end, in a horizontal position, and a sulficient weight suspended at the other end, the bar will break at the point of support; and the following phænomena will take place.

9. The bar will bend, and the bending will be proportional to the extensibility of the material.

10. The upper side of the bar will be extended, and the lower

* Traité du Mouvernent des Eunx, Sect. v. Discours ii.

+ Some experiments of this kind were made by Enerson,-Mechanies, Prop. 76. Ed. 1773. Bersouilli has attempted to demonstrate that the compression cannot be proportional to the force; but his reasoning applies to extreme cases only; and the result of the solitary experiment he made is completely differen from those of every other writer that I have consulted. See his paper in the Mem. de l'Acad. des Scien. Paris 1705, p. 179.

$\$$ Supplement to Eucyelop. Britannica, art. Bridge, p. 497.1817 . 
sicle compressed; but a horizontal stratum of particles, at or near the mildle of the depth, will neither be extended nor compressed. Iluce the line representing this stratum, in the section of the bar, is called the metrral line

11. The extension and compresim of any part of the section is proportional to its distance fram the neutral line.

The quantity of extension and compression, and the position of the neutral line, may be observed in some solt wodd, with a considemble degree of accuracy, by drawing two vertical lines, very near to each other, amaint mise of the vertical sides of the bar at the place of fracture, before the weight is applied.

Sometimes the palts that have heen exiended nay be distinguished from those which bave been compressed by the fracture, and in fibrous substances, by stopping the stescent of the bar before the fracture is completed, the position of the neural line may be ohserved. The last is the best nethod.

Du Hamel narde some experiments on lars of willow, with the view of deremining the porition of the neutral line, by cutting the bars to diferent rejtis, with a saw, on the comprested side*, but this methot is not suscepinsts of nueb acentras.

12. Frommany duservatins, I have livend that wen the sec-

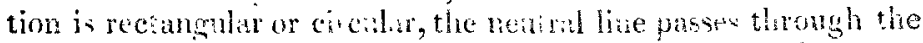

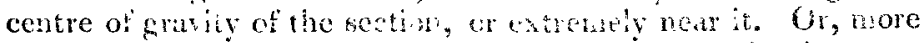

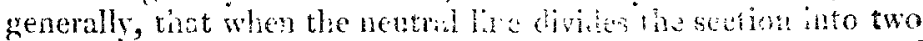

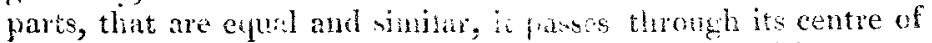
gravity;-and that in trianguar sectons the lsume ef the centre of gravity from the vorex in abrat seven-tenths of the height.

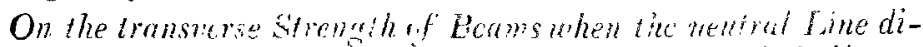
vides the Sertion into the outs that are equal and whilar.

13. Prop. To determine the strength of a bean fixed at one end to support a weight stisneuded at the other end.

Let $\Lambda$ Jo $C$ represent the bean; where $C$ is the point of sup-

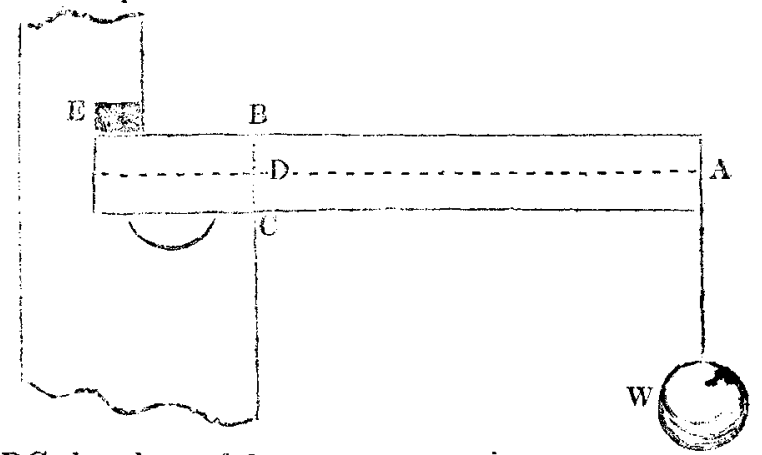

port, BC the place of fracture, and D the place of the neutral line.

* Transport di Bois, p. 419.

Theny 
Then, the weight $W$ will act with the leverage $A D$; and $D$ will be the centre of motion. Now it is evident, that when the weight at $A$ causes the beam to move round the centre $D$, the upper side at $\mathrm{B}$ will be extended and the lower side at $\mathrm{C}$ compressed (art. 10); and the strin on any part above or below the neutral line will be directly as its distance from that line; and the extension or compression will be as the strain (arts. 6 and 11 ).

Also, as the compressed part is the fulcrum which supports the lever till the extended part is torn asunder; and bodies are extended and compressed in equal degrees by equal forces (art.7); therefore, the neutral line must divide the section into two equal and similar parts, because the forces on each side of the neutral line must be eqqual*.

Put $l=$ the length of the beam AD;

$a=$ the distance of the neutral line from the upper side;

$y=$ the breadth of the beam;

$f=$ the cohesive force of an unit of the area;

$y \dot{x}=$ a variable part of the section of fracture;

and $x=$ its distance from the neutral line.

Then the force of any variable part of the section is as its distance from the neutral line, or $a: x:: f: \frac{f x}{a}$; and as its area $y \dot{x}$; hence, its whole force is $=\frac{f y x \dot{x}}{a}$; which being multiplied by its distance from the centre of motion, gives $\frac{f y x^{2} \dot{x}}{a}=$ the fluxion of the force exerted by the part of the beam above the neutral line. But the forces on each side of the neutral line are equal; therefore, in the case of equilitrium, we have

$$
\text { Fluent of } \frac{2 f y x^{2} \dot{x}}{a}=l \mathrm{~W} \text {; or flu. } \frac{2 f y x^{2} \dot{x}}{i a}=\mathrm{W} \text {. }
$$

* Most of the writers on the strength of materials have considered the point of support $\mathrm{C}$, as the fulcrum to the extending forces, but the support is a fulcrum only in respect to a force at $\mathrm{E} ;$ - this mistake arises from the absurd method of demonstrating the properties of the lever, by supposing it to be an inflexible line; had the propertics of the lever been sought for in the lever itself, this could never have happened.

In the natural order of scienee, the resistance of beams should occupy the place that is now assigned to the doctrine of the lever, as its properties are merely so many corollaries which naturally flow from propositions in the doctrine of the resistance of beams. For the strains excited in a beam may be investigated directly by means of the properties of the parallologram of forces, without referting at all to those of the lever; and the properties of a beam considered as a lever, may be deduced from the strains excited in the beam, which appears to be the only legitimate mode of demonstrating its properties. See art. Carpentry, p. 167. Supplem. Encyclo. Brit.3d ed. 1811 ; or art. Carpentry, p.633, New Supp. 1817.
Vol. 50. No.236. Dec. 1817.
D d
14. When 
14. When the beam is rectangular, and its depth $=d$; $a=\frac{d}{2}$; and making $y=b$, we have $\frac{2 f y x^{2} \dot{x}}{l a}=\frac{4 f b x^{2} \dot{x}}{l d}$; the fluent of which is $\frac{4 f l x^{3}}{3 l d}$, and when $x=\frac{d}{2}$, it becomes $\frac{f b d^{2}}{6 b}=$ $W=$ the transverse strength of the beam.

15. When a beam is supported at both ends, its strength to bear a weight in the middle of its length, is to that of a beam of the same length, supporterl at one end, as 4 is to 1 . Hence $\frac{2 f l d^{2}}{3 l}=W=$ the strength of a beam supported at both ends.

16. When the beam is square, and the force acts in the direction of its diagonal $\mathrm{BC} ; \mathrm{EF}$ will be the neutral line, $\mathrm{BD}=a$, and $\mathrm{EF}=2 a$. Also, by sim. trians. $a: a-x:: 2 a$ : $2(a-x)=y$.

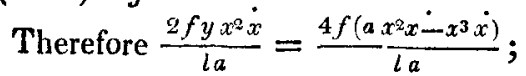
and, when $x=a$, the fluent is $\frac{f a^{3}}{3 l}$, or, because $2 a=d=$ the diagonal; $\frac{t^{i 3}}{24 l}=$

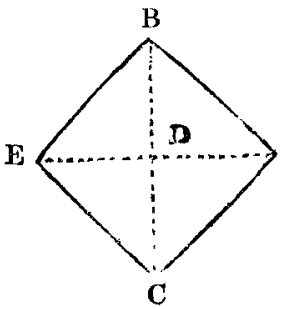
$W=$ the strength of the beam supported at one end.

And when a beam of the same length is supported at both ends, $\frac{f d^{3}}{6 \ell}=W=$ the strength of the beam.

17. When the beam is a cylinder, and its radius $=r ; a=r$, and, by the property of the circle, $y=2 \sqrt{ }\left(r^{2}-x^{2}\right)$.

Therefore $\frac{2 f y x^{2} \dot{x}}{l a}=\frac{4 f x^{2} \dot{x} \sqrt{ }\left(x^{2}-x^{2}\right)}{l \tau} ;$ and its fluent when $x=r$, and $p=3 \cdot 141=5, \& c$. is $\frac{f p r^{3}}{4 l}=\mathrm{W}=$ the strength of $a$ cylinder supported at one end ; or, $\frac{f p^{3}}{l}=\mathrm{W}=$ the strength supported at both ends.

18. From the preceding examples it appears, that when the length and the areas of the sections are the same, the transverse strengths of the beams will be nearly in the following proportion; viz.

The strength of a square beam being unity, or .. 1.000

The strength of the same beam when the force is $\} 0.7071$

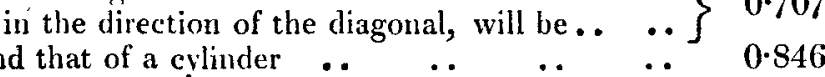

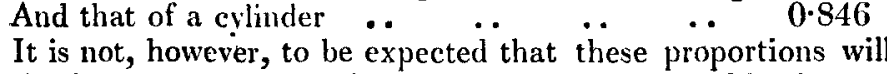
perfectly agree with experiments, unless the material be homogeneous. For this reason, timber is very unfit for the purpose of making experiments to establish a pure mechanical theory. 
When a beam is compressed in the direction of its length, the deflexion is alwavs in the direction of the diagonal, when the section is nearly square; this has been shown by the experiments of Girard, Lamiandé, and Navier; and it is only a modification of the transverse strain, which confirms the general principles of the theory, and at the same time shows that a cylinder is the best form for an insulated post*

19. When the neutral line divides the section into two parts, that are neither equal nor similar; assume the distances of the upper and lower sides of the beam from the neutral line, and find the force exerted on each side of the neutral line by art. 13 . Make those forces equal to each other, and from this equation the distance of the neutral line from the upper sicie may be obtained; which heing substituted for the assumed distance in the expression for the force of the part above the neutral line, will give half the strength of the beam.

In this manner the rule for the strength of a triangular beam has been found, which is inserted in the Philosophical Magazine, vol. xlvii. p. $22 . \dagger$

20. As the colvesion of their parts not only serves to characterize different substances, but also to determine their relative value in the various uses to which they may be appropriated; I have endeavoured to collect from various sources, the best experiments of this important subject; and to present them in the form which appeared to me best adapted to render then capable of universal application.

For this purpose they are reduced to a common standard, from which, by a simple operation, they may be reduced to any kind of weights or measures.

I have adopted plate glass as a stanlard, because it is a substance tolerably uniform in its nature, its defects may be readily perceived, and it is not used where its strength need be calculated; and therefore, the strengths of different kinds of it will not be required. 'The experiments were made on the transverse strength, and the direct cohesion was calculated by art. 14. The pieces were loaded by letting sand run slowly into the scale till they broke. The results were regular, and the highest was taken.

* This remark extends only to the form of the section.

t The rule for the resistance to crushing (Phil. Mag. xlvii. 22) was an attempt to apply the principles which $M$. de prony has used in his investigation of the push of the earth against retaining walls to the resistance to crushing-neglecting the effect of the cohesion in determining the angle of fracture. Since that time I have found that the angle of fracture will vary with the cohesion; therefore any rule where it is neglected can only be a rude approximation. - It may not be improper here to state, that in $M$. de Prony's investigation of the push of the earth, one very material element is omitted; viz. the friction against the back of the wall. The existence and effect of this friction may readily be seen from the results of Col. Pasley's experiments. " Course of Military Instruction," iii. 563. 
Experiments on the direct cohesion of bodies require to be made with much care, in order to obtain correct results, particularly when they are brittle; and it is also very probable that the strength of bodies, to resist being torn asunder, is not exactly as their areas. For if the cohesion be as the area, it does not follow that the strain excited by a force tending to pull the body asunder should be in the same proportion. Indeed, Count Rumford's experinents led him to conclude that the strength is not in the simple proportion of the area*, and Perronet found that when a bar of iron was strained in the direction of its length, a very slight incision made with a file on one side, sometimes reduced its strength more than one-half; which could not have been the case had the strain been equally diffused over the section + .

Hence I conclude, that the length being taken so that the deflexion $\ddagger$ does not sensibly affect the result, the cohesion calcilated from the transverse strength, is as near or nearcr the real cohesion than that obtained by pulling the body asunder.

Morveau very justly observes that the maximum cohesion of the metals ought not to enter into the calculations of the artist who employs them, as it is known that accidental imperfections always accelerate the rupture in a greater or less degree, and render it necessary to augment their dimensions; but it is not less true that their proportional tenacity being known, it would assist the artist in his choice, and furnish the valuable means of ascertaining the degree of purity, and the qualities which are imparted to them in the course of their manufacture $\S$.

It will be seen from the following Tables, that the cohesive force of metals is much increased by wire-drawing, rolling, and hammering; and that the strength of woods of the same kind is extremely variable, depending on the nature of the soil, the situation, and the climate where they are grown.

A complete table ought to exhilit the limits of these variations, and might be made to contain much useful information for the planter and landed proprietor,-but not till experimentalists give better descriptions of the specimens they try, than they have hitherto done.

In the following tables the specific cohesion of plate glass is denoted by unity; and,

The cohesive force of a square inch is 9420 pounds avoirdup.

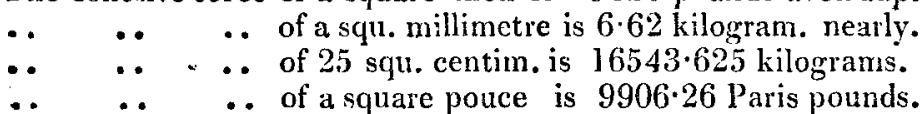

Hence the specific cohesion of a substance multiplied by one of these numbers will give the cohesion in the corresponding weights and measures.

- Phil. Mar. x. 51.

+ Euvres de Gauthey, ii. 150.

\pm On the effect of the deflexion, see Phil. Mag. xlvi. 191.

$\S$ Ann. de Chimie, lxxi. 190. 
TABLES OF THE COFESIVE FORCE OF SOLID BODIES.

\section{TABLE I. - METALS.}

$(h)$ and $(l)$ mark the highest and lowest result which Muschenbroëk obtained from each kind of iron.

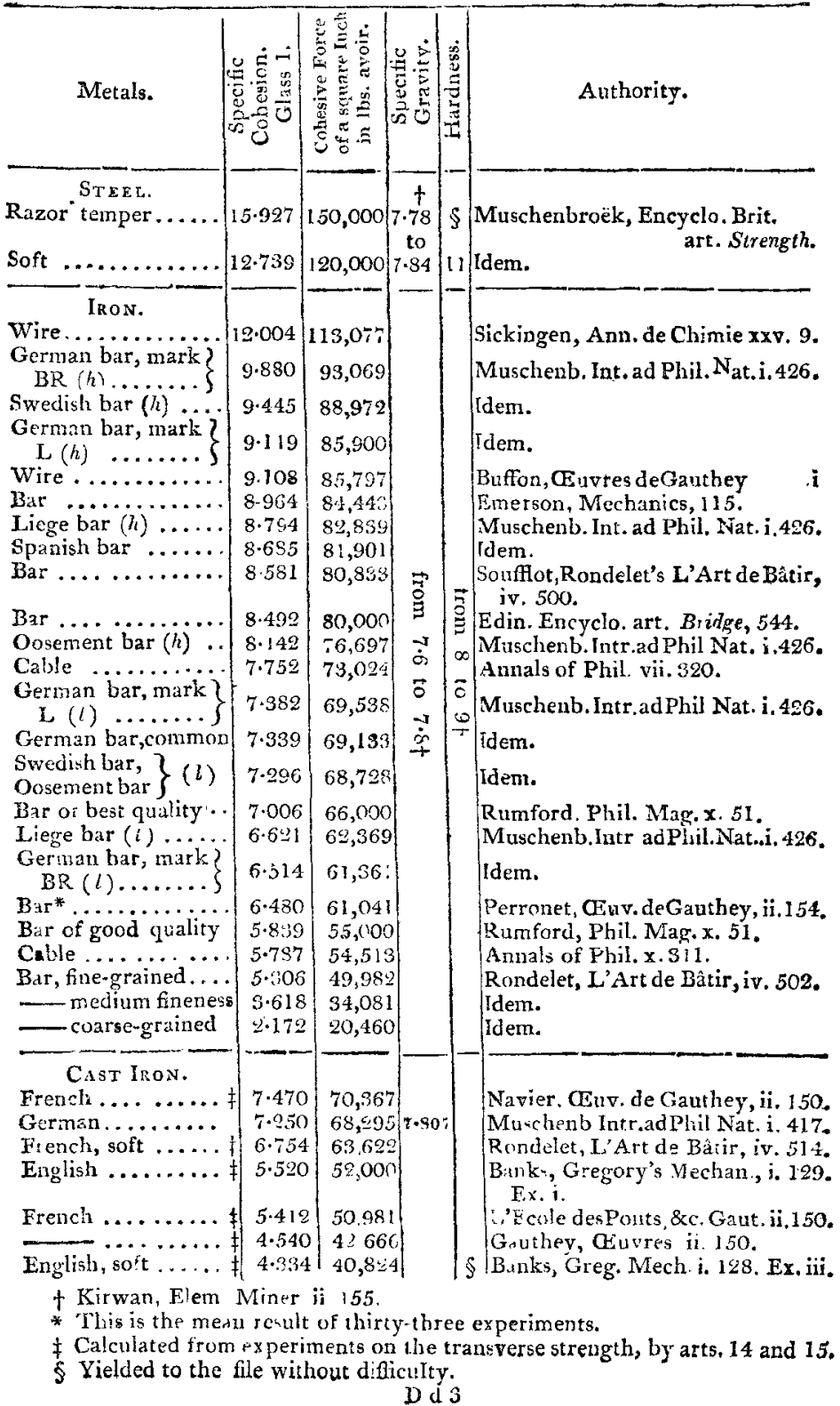


TABLE I - (continued.)

\begin{tabular}{|c|c|c|c|c|c|}
\hline Metals. & 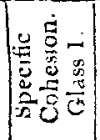 & 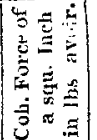 & 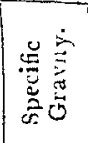 & 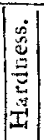 & Authority. \\
\hline $\begin{array}{l}\text { Cast Iron. } \\
\text { French gray ..... } \\
\text { Gray, of Cruzot. } \\
\text { 2d fusion ... } \\
\text { Gray, of Cruzot. } \\
\text { lst fusioni } \ddagger \text {.. }\end{array}$ & $\begin{array}{l}3.257 \\
3.202\end{array}$ & $\begin{array}{l}57,680 \\
50.680\end{array}$ & & & $\begin{array}{l}\text { Rondelet, L'Art de Bâtir, iv. } 514 . \\
\text { Ramus, Gauthey, ii. } 150, \\
\text { Ramus, Gambey, ib. } \$\end{array}$ \\
\hline $\begin{array}{l}\text { Copper. } \\
\text { Wire } \ldots \ldots \\
\text { Cast, Barbary } \ldots \\
\end{array}$ & $\begin{array}{l}6 \cdot 606 \\
2 \cdot 596 \\
2 \cdot 52 \\
\end{array}$ & $\left|\begin{array}{r}61,298 \\
22,570 \\
20,272\end{array}\right|$ & $\begin{array}{r}8 \cdot 189 \\
8.726\end{array}$ & $8+$ & $\begin{array}{l}\text { Sickingen, Ann. de Chimie, xxv. } 9 . \\
\text { Muschenb. Intr. ad Ehil Nat. i.417. } \\
\text { Idem. }\end{array}$ \\
\hline $\begin{array}{l}\text { Platinum. } \\
\text { Wire } \cdots \cdots \cdots \\
\text { Wire } \ldots \ldots \cdots \cdots\end{array}$ & $\begin{array}{l}5 \cdot 995 \\
5 \cdot 625\end{array}$ & $\left|\begin{array}{l}56,473 \\
52,9 \times 7\end{array}\right|$ & $20 \cdot 847$ & $8 \|$ & $\begin{array}{l}\text { Morveau, Ann de Chimie, xxv. } 8 \text {, } \\
\text { Sickingen, Ann. de Chim. xxv. } 9 .\end{array}$ \\
\hline $\begin{array}{c}\text { Silver. } \\
\text { Wire } \ldots \cdots \cdots \cdots \cdots \\
\text { Cast } \ldots \ldots \cdots \cdots \cdots\end{array}$ & $\begin{array}{l}4.090 \\
4.392\end{array}$ & $\begin{array}{l}38,2.5 \\
40,902\end{array}$ & 11.091 & $7^{\mathrm{II}}$ & $\begin{array}{l}\text { Sickingen, Ann de Chim. xxy. } 9 . \\
\text { Muschenb. Intr. ad Phil. Nat.i. } 417 .\end{array}$ \\
\hline $\begin{array}{l}\text { Goud. } \\
\text { Wire............... } \\
\text { Cast } . \ldots \ldots \ldots \ldots\end{array}$ & $\begin{array}{l}3 \cdot 279 \\
2 \cdot 171\end{array}$ & $\left|\begin{array}{l}30,888 \\
20,4,20\end{array}\right|$ & $19 \cdot 288$ & $6+$ & $\begin{array}{l}\text { Sickingen, Ann, de Chim, xxv. } 9 . \\
\text { Muschenb Intr. ad Phil.Nat i.417. }\end{array}$ \\
\hline 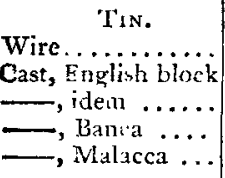 & $\left|\begin{array}{l}0.7568 \\
0.706 \\
0.5 f 3 \\
0.3906 \\
0.342\end{array}\right|$ & $\begin{array}{l}7,129 \\
6,650 \\
5,322 \\
3,679 \\
3,211\end{array}$ & $\left.\begin{array}{r} \\
7 \cdot 295 \\
7 \cdot 2165 \\
6 \cdot 12 \div 6\end{array}\right)$ & $6+1$ & $\begin{array}{l}\text { Morveau, Ann. de Chin. Ixxi, } 194 . \\
\text { Muschenb. Intr.ad Phil.Nat. i.41\%. } \\
\text { Idem. } \\
\text { Idem. } \\
\text { Idem. }\end{array}$ \\
\hline $\begin{array}{l}\text { Bismutn } \\
\text { Cast } \\
\cdots \\
\cdots \cdots \cdots \cdots \cdots\end{array}$ & $\begin{array}{l}0.345 \\
0.3193\end{array}$ & $\begin{array}{l}3,250 \\
3,008\end{array}$ & $\left\{\begin{array}{l}9 \cdot 810 \\
9 \cdot 920\end{array}\right\}$ & 71 & $\begin{array}{l}\text { Muschenb. Intr. ad Phil.Nat.i.417. } \\
\text { Idem, i. 454. }\end{array}$ \\
\hline $\begin{array}{l}\text { Zınc, } \\
\text { Wire........... } \\
\text { Patent sheet } \\
\text { Cast, Guslar, from } \\
\text { to } .\end{array}$ & $\left|\begin{array}{l}2 \cdot 394 \\
1 \cdot 762 \\
0 \cdot 3118 \\
0 \cdot 2855\end{array}\right|$ & $\left|\begin{array}{r}22.5 .51 \\
16,616 \\
2,937 \\
2,689\end{array}\right|$ & $7 \cdot 2 i 5\}$ & & $\begin{array}{l}\text { Morveau, Ann de Chim. lxxi. } 194 . \\
\text { By my trial. } \\
\text { Muschenb. Intr. ad Phil.Nat.i.417. }\end{array}$ \\
\hline 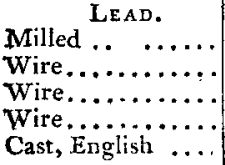 & $\left|\begin{array}{l}0 \cdot 3539 \\
0 \cdot 334 \\
0 \cdot 274 \\
0 \cdot 2704 \\
0 \cdot 094\end{array}\right|$ & $\begin{array}{r}3,928 \\
3.146 \\
2,581 \\
2,547 \\
885\end{array}$ & $\left.\begin{array}{l}11.407 \\
11.348 \\
11.282 \\
11.479\end{array}\right\}$ & \{ & $\begin{array}{l}\text { By my trial. } \\
\text { Musclienb. Intr. ad Phil.Nat. i.45a. } \\
\text { Idem. } \\
\text { Morveau, Ann. de Chim. Ixzi. } 194 . \\
\text { Muschenb. Intr. ad Phil. Nat. i.452. }\end{array}$ \\
\hline & & & & & Phil \\
\hline
\end{tabular}

$\$$ In the operation of casting, the surface of the iron always becomes much harder, and is more tenactous than the internal parts; hence, the strength of a small specimen is always greater than that of a larae one. Those of M. Ramus, however, are unexceptionable in this respect, as the area of the section at the place of tracture was above nine square inches

N. B. When the specific gravity is not referred to a separate authority, it is to be considered that of the specimen of which the cohesive force is given.

t Kirwan's Miner. vol. ii. \Thomson's Chemistry, vol, i, 


\section{On the Resistance of Solids.}

TABLE II -ALLOYS.

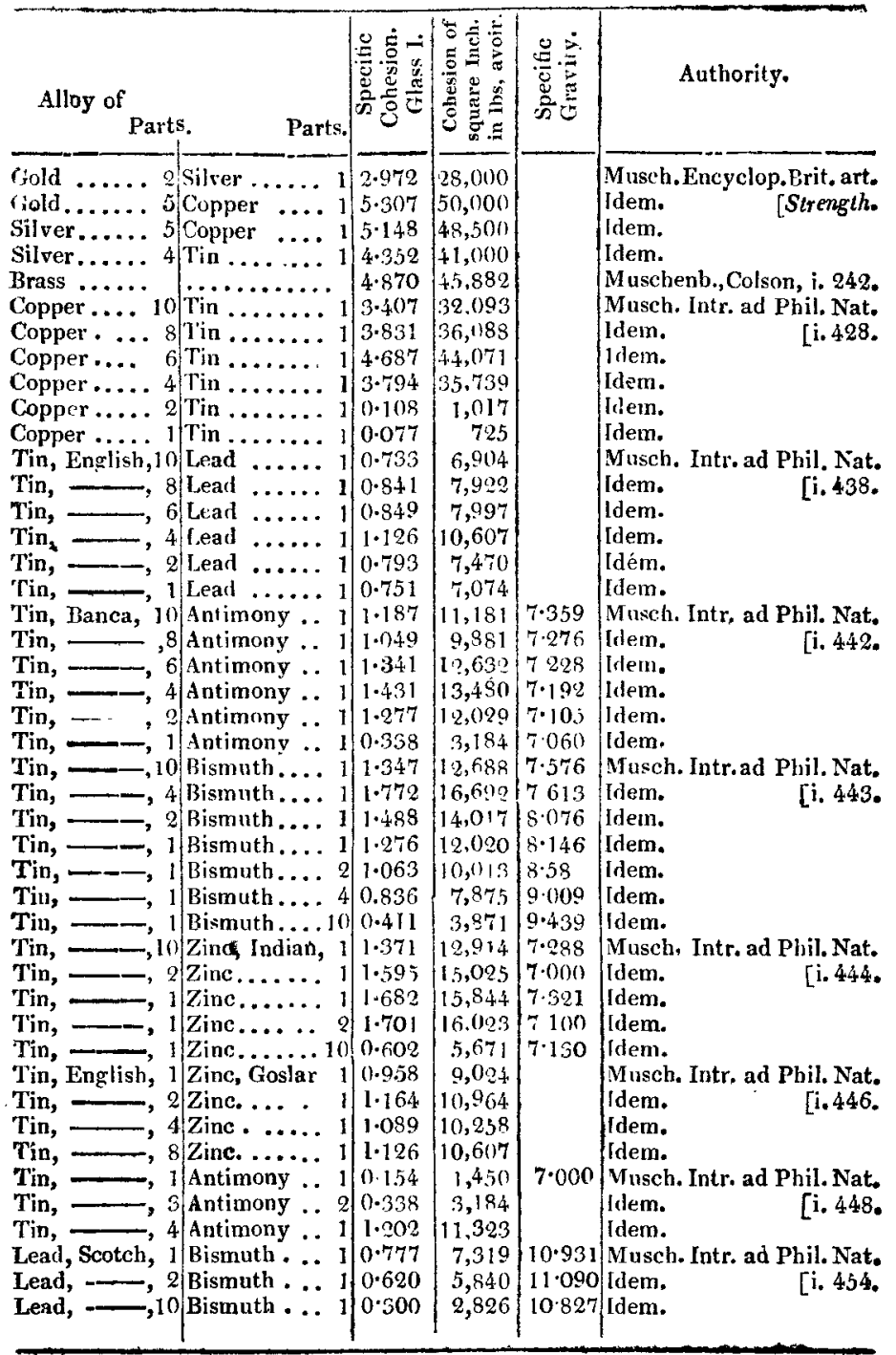


TABLE III-WOODS.

\begin{tabular}{|c|c|c|c|c|}
\hline Woods. & 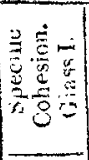 & 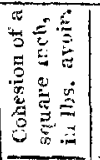 & 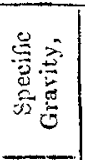 & Authority. \\
\hline Lance-wood .... t & $2 \cdot 62 !$ & 24,796 & 1022 & Iayman, Nich. Journal, xxxv. 54. \\
\hline Locust-tree ...... & $2 \cdot 185$ & 31,582 & & Muschenb. Iutr. ad Phil. Nat. i. 415. \\
\hline $\begin{array}{c}\text { Jujube (Ziziphns) } \\
\text { Asm (Fraxiniss.) }\end{array}$ & 9.008 & $11,9: 5$ & & Idem, $\quad \ldots \quad \quad \cdots \quad$ i. 414. \\
\hline Red, scasoned ... & 1.899 & 17,592 & $0.81 \pm$ & Layman, Nich Journal, xxxv. 54 . \\
\hline$A \operatorname{sh} \ldots \ldots \ldots \ldots$ & $1 \cdot 864$ & 17.000 & & Barlow, hees's Cyclop. art. Strength̆. \\
\hline White, sea & $1 \cdot 509$ & $1,1,020$ & 0.68 .5 & Layman, Nich. Journal, xxxv. 54 . \\
\hline $\begin{array}{c}\text { Ash } \\
\text { OAK }(Q \operatorname{Qiercu})\end{array}$ & l.t.27 & 12,000 & & Muschenb. Ency. Brit, art, Strength. \\
\hline Oak ..... & $1 \cdot 591$ & $: 7,020$ & & Fmerson's Mechanies, 114. Ed. \\
\hline- , highes & & 532 & & Eanks, Gregory's Mechan. i. 127. \\
\hline$\overline{\text { Dryt }}, \ddot{\mathrm{cut}}$ & 1.836 & 17,500 & & Muschenb. Ency. Brit., art. Strength. \\
\hline Dry, cut 4 & 1.707 & 16,079 & & Duhamel, Transport du Buis, p. 212. \\
\hline Provence, & 1.559 & 14,685 & $1 \cdot 164$ & Idem, \\
\hline English, seasoned, & 1.509 & 14,920 & 0.880 & Layman, Nich. Jour. xxxv. 54. \\
\hline Oak $\ldots \ldots \ldots \ldots$ & $1 \cdot 481$ & 13,951 & & Pondelet, LArt de Bâtir, iv. 65 . \\
\hline Frenci, season. $i$ & $1 \cdot 450$ & $: 3,6.59$ & & Duhamel, Trans. du Bois, 213 . \\
\hline Provencescason. $\|_{1}$ & $1 \cdot 444$ & 13,602 & 0) 328 & Idem, $\quad \ldots \quad \ldots \quad 423$ \\
\hline $\begin{array}{l}\text { Provence, season. } \\
\text { young } \ldots+\ldots+\}\end{array}$ & $1.56 \hat{3}$ & 12,839 & 0.771 & Idem, $\quad \ldots \quad \ldots \quad 230$. \\
\hline Oak, dry ...... & $1 \cdot 274$ & 12,000 & & Muller, Pract. Fortification, 76. \\
\hline Baltic, scasoned & $1+211$ & 11,412 & 0.673 & Layman, Nich. Jour, xxxv. 5t. \\
\hline Oak, lowest result & $1 \cdot 146$ & 810 & & Banks, Gregory's Mech.j. 127. \\
\hline$\overline{\text { English, }}, \ldots$ & $\mid \begin{array}{l}1 \cdot 107 \\
1 \cdot 085\end{array}$ & $\begin{array}{l}488 \\
294\end{array}$ & & $\begin{array}{l}\text { Belitor, Scien. des!ngen.3i9. Ed.1815. } \\
\text { Benufoy, Ann. Phil.ix, 286. Ex. No.4. }\end{array}$ \\
\hline $\mathrm{Oak}, \ldots \ldots \ldots \ldots+$ & $1 \cdot 076$ & 10,136 & & Belidor, Scien. dea Ing. 321 . Ed.1813. \\
\hline French, unseason, + & $1 \cdot 060$ & $9,98.5$ & 1.068 & Buffun, Mém. de l'Acad. Paris, 1741 , \\
\hline $\begin{array}{l}\text { White American, } \\
\text { sezsoned ... }+\}\end{array}$ & $1 \cdot 009$ & $9,50 \%$ & & Layman, Nich. Jour. xxxv, 54. \\
\hline Oak, ......... & $1 \cdot 009$ & $9,50+$ & & Barlow, Rees's Cyclo, art. Strength. \\
\hline French, unseason. & 0.960 & 9,043 & & $\begin{array}{r}\text { Buffon } §, \text { Mém. de l'Acad. Paris, } 17+1 \text {, } \\
\text { 328. }\end{array}$ \\
\hline Oak & 0.955 & 9,000 & 0.774 & Barlow, Rees's Cyclop. art. St ength. \\
\hline Fn:lish.. & 0.930 & 8,820 & & Scalloy, Ann. of Phil ix. 297. Ex.10 \\
\hline & 0.818 & 7,704 & & Idem, $\quad \cdots \quad \cdots \quad$ 233. Ex.19. \\
\hline $\begin{array}{c}\text { Beech (Fayus } \\
\text { sylvatious) } \ldots\end{array}$ & $1 \cdot 880$ & 17,709 & & Muschenb. Intro, ad Phil. Nat. i. 415. \\
\hline Arbutus, from.. & $\begin{array}{l}1.845 \\
0.814\end{array}$ & $\begin{array}{r}17,379 \\
7,667\end{array}$ & & Idem, \\
\hline $\begin{array}{c}\text { Orange (Auran- } \\
\quad \text { tium) } \ldots \ldots \ldots\end{array}$ & 1.76 & 16,616 & & Idem. \\
\hline Bay (Laurus) & $\begin{array}{l}1 \cdot 629 \\
1 \cdot 5+7 \\
1 \cdot 085\end{array}$ & $\mid \begin{array}{l}15,345 \\
14,572 \\
10,220\end{array}$ & & Idem. \\
\hline
\end{tabular}

* Its colour brown; and it was hard and large-reined.

+ This specimen lay six munths in water after it was cut, and was afterwards dried. When the trial was made it had been cut four years.

If Midäle-aged timber, fint-veined, light and pliant.

$\$$ To find the distance between the supports, in Buffon's experiments, I deducted one-twelfth of the length of the piece, according to the notice he has given in the beginning of his memoir; the two results given are the highest and lowest from the eight-feet lengths. 
TABLE III.-(continued.)

\begin{tabular}{|c|c|c|c|c|}
\hline Woods. . & 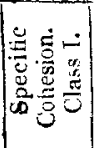 & 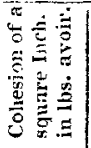 & 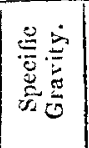 & Authority. \\
\hline $\begin{array}{l}\text { TEAK (Tectona }_{\text {L.Ands). }} \\
\text { grandis }\end{array}$ & & & & \\
\hline Java, seasoned, ... & $1 \cdot 509$ & 14,920 & 0.697 & Layman, Nich. Journ. xxxv. 54. \\
\hline Peg & 1.400 & 13,194 & $0 \cdot 619$ & Idem. \\
\hline ned, $;$ & 1.895 & 13,140 & 0.688 & $\begin{array}{l}\text { ldem. } \\
\text { Muschenb. Intr, ad Phil. Nat, i, } 414 .\end{array}$ \\
\hline $\begin{array}{l}\text { Alder (Bet. Alnus) } \\
\text { M ulberry(Morus) }\end{array}$ & $\begin{array}{l}1.506 \\
1.492\end{array}$ & $\mid \begin{array}{l}14,186 \\
4,054\end{array}$ & & schenb. Intr. ad Phil. Nat. i. 414 \\
\hline 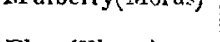 & $\mid \begin{array}{ll}1 \\
1.928\end{array}$ & 11,501 & \} & Idem. \\
\hline $\begin{array}{l}\text { Elm (Ulmus) } \ldots \\
\text { FIRS (Pinus). }\end{array}$ & $1 \cdot 432$ & 13,489 & & !dem. \\
\hline Pitch pine, ......t & 1.398 & 13,176 & & Layman, Nich. Journ. xxxr. 54. \\
\hline Fir $\ldots \ldots \ldots \ldots$ & $\mid \begin{array}{l}1 \cdot 380 \\
1 \cdot 318\end{array}$ & $\begin{array}{l}13,000 \\
12,400\end{array}$ & & $\begin{array}{l}\text { Barlow, Rees's Cyclop, art. Strength. } \\
\text { Banks, Grecory's Mech i. } 127 \text {. }\end{array}$ \\
\hline Pitch pine, .... & $1<284$ & 12,096 & & Beaufoy, Ann. of Phil. ix. 304, 305. \\
\hline $\left.\begin{array}{l}\text { Pine (Pin du } \\
\text { Nord) }, \ldots \ldots+\}\end{array}\right\}$ & $1 \cdot 264$ & 11,913 & & Duhamel, Transpurt du Bois, 460 \\
\hline $\left.\begin{array}{l}\text { Larch } \\
\text { Larix) }\end{array}, \ldots \ldots+\right\}$ & $1 \cdot 174$ & 11,093 & 0.636 & By my trials. $f$ \\
\hline $\begin{array}{l}\text { Fir, strong red, .. } \\
\text { Fir, Memel,season }\end{array}$ & $\left\{\begin{array}{l}1 \cdot 172 \\
1 \cdot 154\end{array}\right.$ & $\begin{array}{l}11,040 \\
10,876\end{array} \mid$ & & $\begin{array}{l}\text { Muller, Pract. Fortification, } 76 \text {. } \\
\text { By my trial. }\end{array}$ \\
\hline Fir, Russian .... & $1 \cdot 0$ Q & 10,008 & 0.459 & Layman, Nich. Journ. xxxv, 54 \\
\hline Fir ..... & 1.061 & 10,000 & & Barlow, Rees's Cyclop, art. Strength. \\
\hline & $1 \cdot 0.39$ & 9,792 & & Irtem. \\
\hline Fir, Riga .... & $0-963$ & 9,072 & & Braufuy, Ann. of Phil ix. 290, 291. \\
\hline Fir, American & 0.942 & 8,874 & 0.416 & Layman, Nich. Journ. xxxv. 54, \\
\hline Fir $\ldots \ldots \ldots$ & 0.903 & 8,506 & & Muschenb. Intr. ad Phil. Nat, i. 414 \\
\hline $\begin{array}{l}-\overline{\text { Fir, yellow deal }} \text { weakest. . } \\
\text {. }\end{array}$ & $\begin{array}{l}0.900 \\
0.879\end{array}$ & $\begin{array}{l}8,48 \\
8,280\end{array}$ & 0.472 & $\begin{array}{l}\text { Layman, Nich. Journ. xxxv. } 54 . \\
\text { Banks, Gregory's Meeh, i. } 127 .\end{array}$ \\
\hline $\begin{array}{l}\text { Larch, Scotch, } \\
\text { seasoned ... }\end{array}$ & 0.837 & 7,888 & 0.496 & Layman, Nich. Journ. xxxv, 54. \\
\hline Pitch pine $\ldots .$. & 0.830 & 7,818 & & Muschenb. Intru, ad Phil. Nat. i, 414. \\
\hline $\left.\begin{array}{l}\text { Larch, Scotch, } \\
\quad \text { very dry, .. }\end{array}\right\}$ & 0.745 & 7,020 & 0.470 & $\begin{array}{l}\text { By my trial, very young wood, the la- } \\
\text { teral cohe bion between the annual }\end{array}$ \\
\hline $\begin{array}{c}\text { Fir, Scotch } \\
\text { sylvestris) }\end{array}\left(\begin{array}{l}P . \\
+\end{array}\right\}$ & $0 \cdot 711$ & 6,600 & 0.550 & By my trials, it was seasoned. \\
\hline Fir, white deal & $0 \cdot 4.55$ & 4,290 & 0.498 & By my trials, very dry. \\
\hline $\begin{array}{l}\text { Sissor, } \\
\text { Saul, }\end{array}$ & $\begin{array}{l}1.345 \\
1.1345\end{array}$ & $\mid \begin{array}{l}13,140 \\
0\end{array}$ & $\begin{array}{l}0.889 \\
0.062\end{array}$ & Layman, Nicb. Joura. xxxv, 54. \\
\hline $\begin{array}{l}\text { Saul, of } \\
\text { Plum, (1 }\end{array}$ & {$\left[\begin{array}{ll}1 \cdot 375 \\
1 \cdot 307\end{array}\right.$} & $\begin{array}{l}12,960 \\
12,782\end{array}$ & 0.96 & \\
\hline Willow & $1 \cdot 9015$ & 11,351 & & Muschenb. Intr. ad Phil. Nat, j. 415 . \\
\hline $\begin{array}{l}\text { Willow (Salix) } \\
\text { Willow, dry ... }\end{array}$ & $\left\{\begin{array}{l}1 \cdot, 5,5 \\
0.8098\end{array}\right.$ & $\begin{array}{r}12,782 \\
7,628\end{array}$ & & $\left\{\begin{array}{l}\text { [dem. } \\
\text { Duhamel, Trans. du Bois, } 419 .\end{array}\right.$ \\
\hline
\end{tabular}

† The specimen was taken from the middle between the centre and sapwood, about three feet from the root; - the diametcr of the tree was nearly 18 inches, and the wood from which the specimen was taken had been cut into two-inch planks about six months. The wood was trugh, harr, and weighed $39 \frac{3}{4}$ pounds per cube foot; - the distance of the annual rings was about an eighth of an inch, and the wood appeared silky when planed. It was grown upon the Duke of Athol's estate at Blair, in Scotland ; and the experiments were made at the desire of William Atkinson, Esq. Architect to the Ordnance, \&c. 
TABLE III.-(continued.)

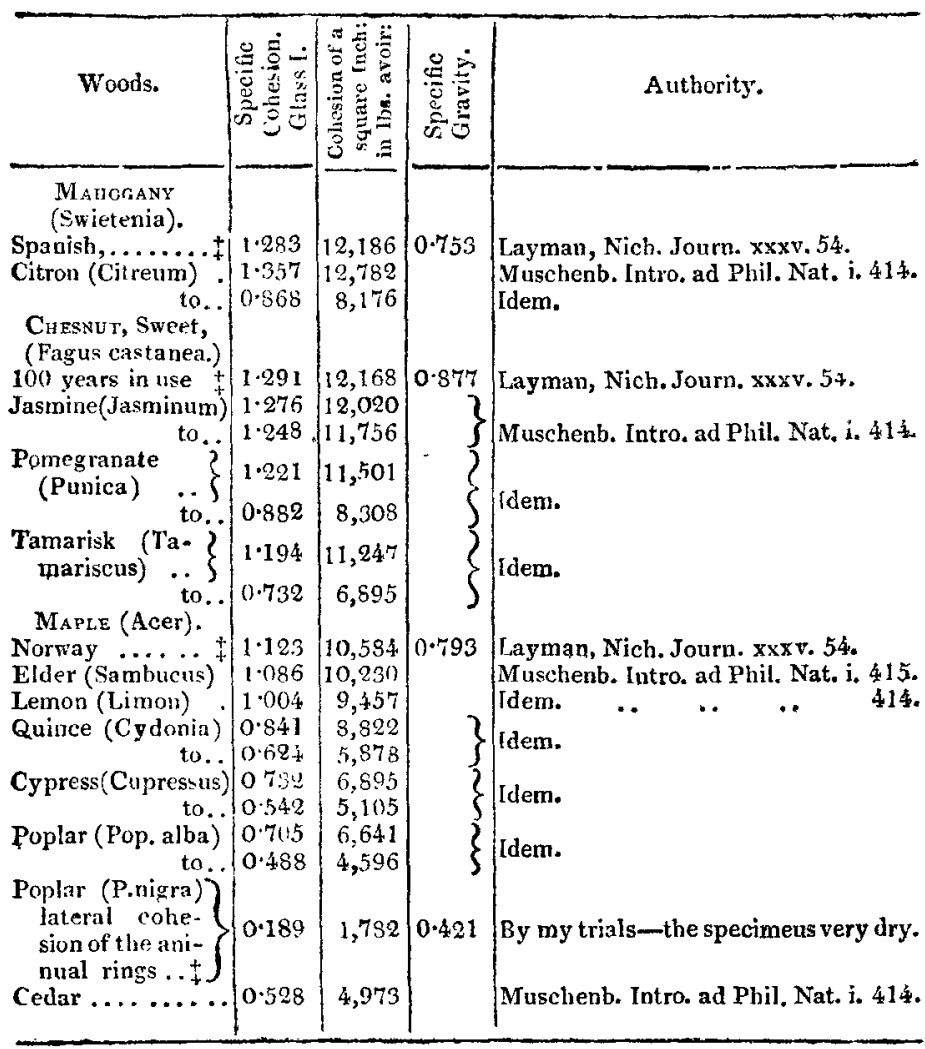

\$ Those to which this mark is added were calculated from experiments on the traasverse strength. 
TABLE IV.-MISCELLANEOUS SUBSTANCES.

\begin{tabular}{|c|c|c|c|c|}
\hline Substances. & 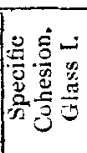 & 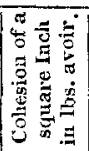 & 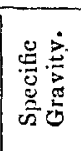 & Authority. \\
\hline Hemp fibres $\}$ & $9 \cdot 760$ & 92,000 & & Rumford, Phil. Mag.x. \\
\hline $\begin{array}{l}\text { Paper strips } \\
\text { glued together }\end{array}$ & $3 \cdot 194$ & 30,000 & & Idem. \\
\hline Ivory $\ldots \ldots \ldots$. & 1.765 & 16,696 & & Muschenb. Intro, ad Phil. Nat, i. 463 \\
\hline $\left.\begin{array}{l}\text { Slate, Welsh, } \\
\quad \text { (clay slate) }+\ldots\end{array}\right\}$ & 1.358 & 12,800 & & By my trials. \\
\hline $\begin{array}{l}\text { Plate-glass } \ldots . .+ \\
\text { Marble (white) }\end{array}$ & 1.000 & $\begin{array}{l}9,420 \\
9,000\end{array}$ & 2453 & By my trials. \\
\hline Horn of an ox .... & $0.95 r^{\prime}$ & 8,040 & & Muschenb, Intro, ad Phil. Nat. i. 463. \\
\hline Whalebone...... & 0.814 & 7,607 & & Iflem. \\
\hline Bone of an ox .... & 0.559 & 5,265 & & Idem. \\
\hline $\left.\begin{array}{c}\text { Hard ston }+ \text { of } \\
\text { Givry } . . .+\end{array}\right\}$ & 0.230 & 2,160 & $2 \cdot 357$ & Gauthey, Roz.Journ.dePhysiq.jv.413. \\
\hline $\begin{array}{r}\text { Portlaud strone, } \\
\text { (commart lime- } \\
\text { stone), ..... }\end{array}$ & 0.083 & 784 & & By my trials. \\
\hline $\left.\begin{array}{l}\text { Soft stome } * \text { of } \\
\text { Givis, .....t }\end{array}\right\}$ & $0.0+1$ & 385 & 2041 & Gauthey, Roz.Journ.dePhysiq. iv.313. \\
\hline Brick from ...... & 0.031 & 300 & & Coulomb, Young's Nat. Phil. ii. 174. \\
\hline $\begin{array}{l}\text { Brick from Dork- } \\
\text { ing, ......t }\end{array}$ & 0029 & 275 & & $\begin{array}{l}\text { By my trial,-colour deep-brick red, } \\
\text { brittle. }\end{array}$ \\
\hline $\begin{array}{r}\text { Stone, bonagene- } \\
\text { ons white, of a } \\
\text { fine grain.... }\end{array}$ & 0.022 & 207 & & Coulomb, Gurres de Gauthey, i. 277. \\
\hline $\begin{array}{l}\text { Plaster of Paris... } \\
\text { Mortar of sand }\end{array}$ & 0.0077 & 72 & & Rondelet, L'Art de Bâtir, i. 314. \\
\hline $\left.\begin{array}{l}\text { and lime, } 16 \\
\text { years made } . .\end{array}\right\}$ & 0.0054 & 50 & & Idem. \\
\hline
\end{tabular}

In our inquiries respecting the laws which regulate the phanomena of nature, we must always exclude certain circumstances which are not necessary, nor do not always accompany the phænomena.

This principle of exelusion is one of the most prominent fea-

+ This stone was hard, of a red colour, and the bells distinctly marked.

* This stone was white, rather soft, and the beds not distinctly marked. These numbers were calculated from experiments on the transverse strength, because the experiments which fauthey made on the suspending strength are so extremely irregular. He appears to have been aware of the principal cause, which was owing to his mole of fixing the pieces. The results of Gauthey's experinents on the suspending strength of stones have been, by mistake, copied as experiments on rrishing, hy Professor Robison, in his article Strength of Materials, Encyclo. Brit. See 4th edition, p. 759. This mistake has been copied by some other writers from the article above mentioned, and among others by the writer of the article Strength, Piees's Cyclopædia.

Gauthey's experiments on crushing are much more numerous and regular. See liozier's Journal de Pbysique, iv. 406 . 
tures of Bacon's method of reasoning*; and has been the guide of Newton in his noble discoveries.

In the resistance of solids, we must consider them homogeneous - that they may be extended and compressed in equal degrees by equal forces and proportionaliy by proportional forces, at least till it is shown by unexceptionable experiments on homogeneous bodies, that these priuciples are not consistent with the phronmena.

The effect of the deflexion should not be excluded in a perfect theory; but it has been omitted in calculating the preceding tables to save ealculation, as it doubles the labour, while the corrections from introducing are too trifling to sensibly affect the result. Besides, such niceties are not needed for practical purposes, whre simplicity is much more esteemed.

Timber is not honogeneous; and therefore it is not a proper material to verify the theory. I have found the transverse strengths of two pieces, of the same size, cut from the side of each other, to be as 9 to 12 . Duhamel found pieces of the same size, and from the same zone, to be as 57 to 66 ; ; - these different resultis were caused by varying the position of the annual rings. The difference of specimens, from the same tree, both in weight and cohesive force, has heen shown by Buffon $¥$. Now when such differences are found in the same tree, is it wonderful that experiments, made in different countries, on wood of different ages, scasoned by different methods, and grown on different soils, should differ from one another?-Is it not yather to be wondered at, that they should agree so nearly as they do? Yet, how often has the correctness of these experi. ments been called in question where it was almost impossible that the writers could he mistaken!

LXXI. Some further Olistryations on the Use of the Colchicum autumnale in Goul. By Sir E. Home, Bart., V.P.R.S.§

I calv lefore the Society, some experiments and ohservations in favnur of this medicine acting upon the gout through the medium of the circulation, and not by its effects directly upon the stomarh and intestinal ennal.

The olject of the present paper is to show that the infusion throws diswn a depreit, the separation of which does not appear to diminisi the specific effects upon the gout, and renders those uyon the stmach and intertines milder than when the deposit is taken along with the infusion.

- Nov. Ogan. lib. ï. Aph. 18. + Transport du Bois, p.460 and 470.

\pm Mem. de l'Acad. Scien. Paris, 1741 , p. $328-332$.

$\$$ From the Transactions of the Royal Society, 1817, part ii.

The 